\title{
THE DYNAMICS OF RUSSIA'S KEY STOCK-MARKET INDICATORS IN JANUARY 2015

\author{
E.Gorbatikov, E.Khudko
}

The period under review - between 23 December 2015 and 26 January 2016 saw the Brent crude price slide further by $12.7 \%$ from the previous period. During that period, there were days when the price dropped below $\$ 30$ a barrel. Sberbank and VTB lost $8.3 \%$ and $12.6 \%$ respectively, thus dragging down Financials Indices and cutting their share of the MOEX (Moscow Exchange) cap by more than 1\%. LUKOIL outperformed Norilsk Nickel to regain the thirdlargest share of MOEX total turnover. The MICEX Index was down $1.1 \%$ to 1705.0 index points. The domestic corporate bond market continued to face the downtrend driven by troublesome external conditions and heightened domestic economic risks. Investors' activity dropped considerably due to the foregoing factors plus the traditional seasonal slack. Nevertheless, the key indicators such as corporate bond market volume and index saw moderately positive dynamics; investors and issuers activity remained at high level. The main headwind was the increase, small though it was, in the weighted average yield rate of bond issuances, as well as the worsening of the issue of Russian companies defaulting on debt obligations due to their bondholders.

\section{The dynamics of the Russian stock market's key structural indices}

Brent crude saw its price sinking for three consecutive months. It was traded at $\$ 36.26$ a barrel at the opening of the period under review, and then dropped to $\$ 30$ on 13 January and to $\$ 28.83$ on 18 January $^{1}$. Despite a small growth in the final week of the period under review, the price lost $12.7 \%$. In the final quarter - between 26 October 2015 and 26 January 2016 - the price was down $33.1 \%$. The MICEX Index was holding the ground amid falling oil prices; it was down more than $8 \%$ during the week between 11 and 15 January, but by the end of the period under review, it rebounded to the level seen earlier in the month. The Index lost a total of $1.1 \%$, down from 1723.4 to 1705.0 index points.

Most of the MOEX-traded blue chip stocks kept falling. Only three highly liquid companies ${ }^{2}$ managed to stay up by the end of the period under review. Rosneft and Magnit, whose stock lost in value a month earlier, showed the best month-end results, up $3.1 \%$ and $1.8 \%$, respectively. VTB Bank, which a month earlier took the lead in terms of

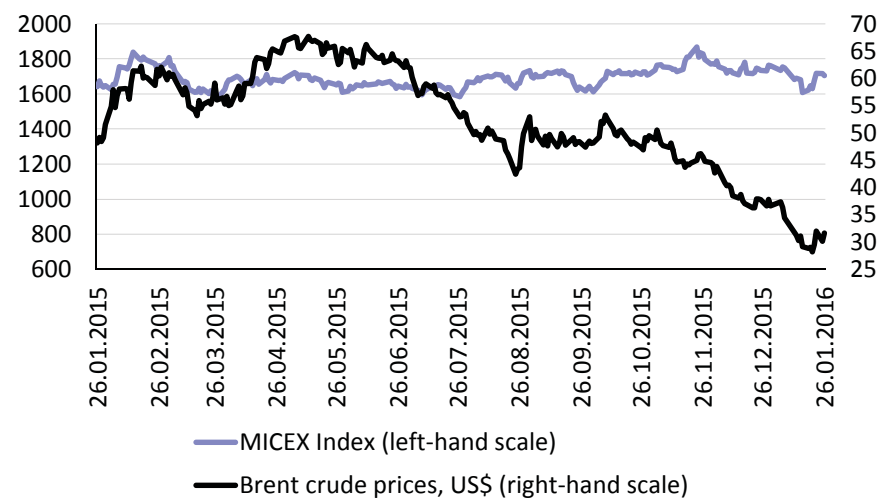

Sources: Quote RBC, Finam.

Fig. 1. The dynamics of the MICEX Index and Brent crude futures in the period between 26 January 2015 and 26 January 2016

1 The data hereinafter refer to MICEX closing data.

2 Highly liquid companies hereinafter refer to companies with an average daily stock trade volume above $\mathrm{Rb} 1 \mathrm{bn}$ during the period under review. 


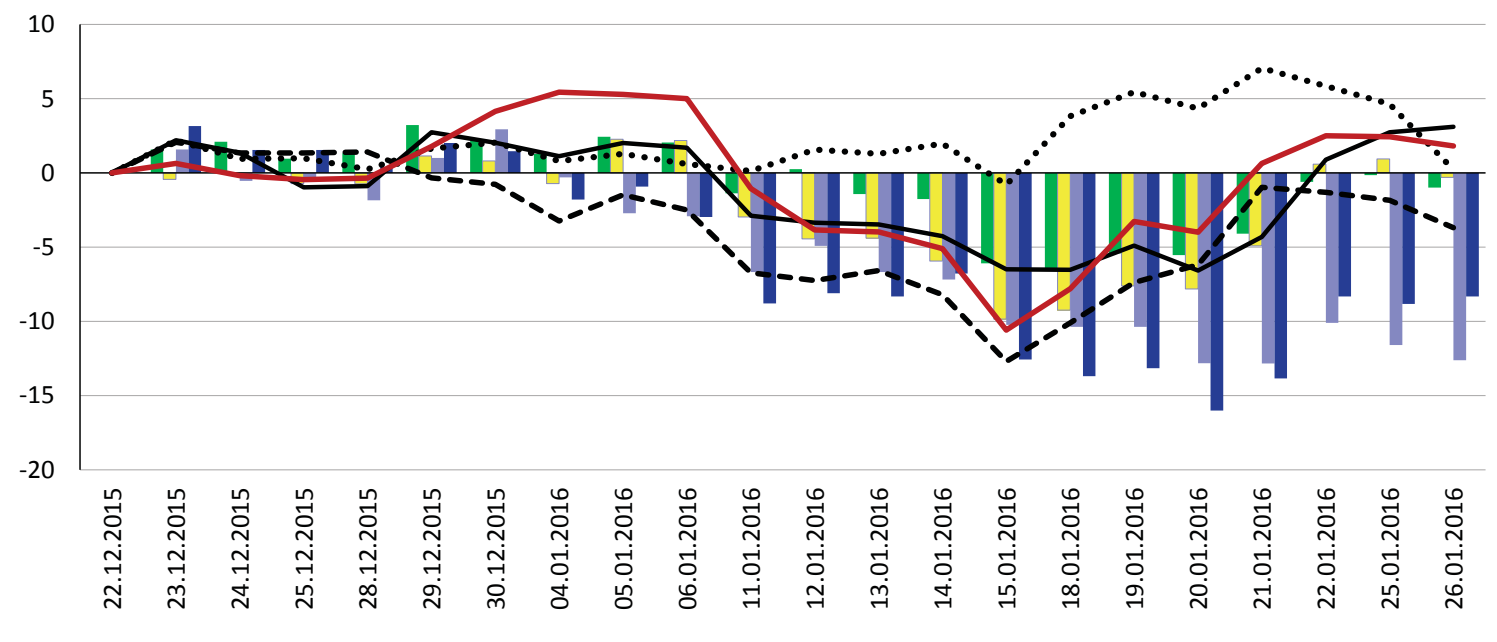

Gazprom $\square$ LUKOIL $\square$ VTB $\square$ Sberbank... .. Surgutneftegaz's pref. stock — Rosneft - - Norilsk Nickel $\longrightarrow$ Magnit

Sources: Quote RBC, author's calculations.

Fig. 2. Quotation growth rates for liquid Russian stocks on the Moscow Exchange in the period between 23 December 2015 and 26 January 2016

ROE, lost $12.6 \%$, the deepest sinking among the blue chip stocks in the period under review. Sberbank lost $8.3 \%$, more than $14 \%$ in the past two months. Norilsk Nickel, which was driven by negative dynamics for three consecutive months, lost $3.7 \%$ in the same period.

Despite the market downtrend, Sberbank continued to outperform other blue-chip stocks in delivering annual rouble-denominated ROE, up more than $50 \%$ y-o-y. Like in the previous period under review, Surgutneftegaz and VTB preferred

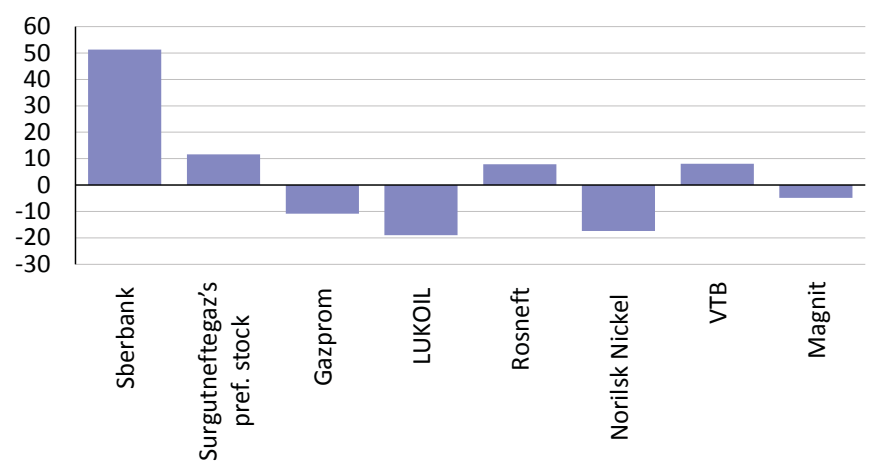

Sources: Quote RBC, authors' calculations.

Fig. 3. Growth rates in the value of highly liquid Russian stocks in the Moscow Exchange in the period between 26 January 2015 and 26 January 2016 stocks were the second and the third best in delivering annual ROE, up $11.6 \%$ and $8.1 \%$ respectively. Rosneft delivered almost the same annual ROE. Norilsk Nickel (down 17.4\%) and LUKOIL (down 19.0\%) delivered a considerably negative ROE at year's end. Magnit and Gazprom were slightly in the red at 2015 year-end.

None of the sector indices showed high growth rates by the end of the period under review. Metals \& Mining Indices and Oil \& Gas Indices (up $3.1 \%$ each), which showed the slowest growth rates in the previous period under review, delivered the best results. Financials Indices expectedly lost more than other indices at that period (7.1\%) (Sberbank and VTB were largely responsible for the fall). Transport Indices (down 3.1\%) were in the red too, once again dragged down mostly by Aeroflot, whereas Chemicals Indices (down $0.8 \%$ ) took the lead in delivering the best results during the period under review. Electric Utilities Indices, Industrial Indices and Telecoms Indices showed a symbolic growth.

Moscow Exchange's (MOEX) turnover contracted for two consecutive months. MOEX total turnover stood at $\mathrm{Rb} 640.5 \mathrm{bn}$ during 21 trading days 


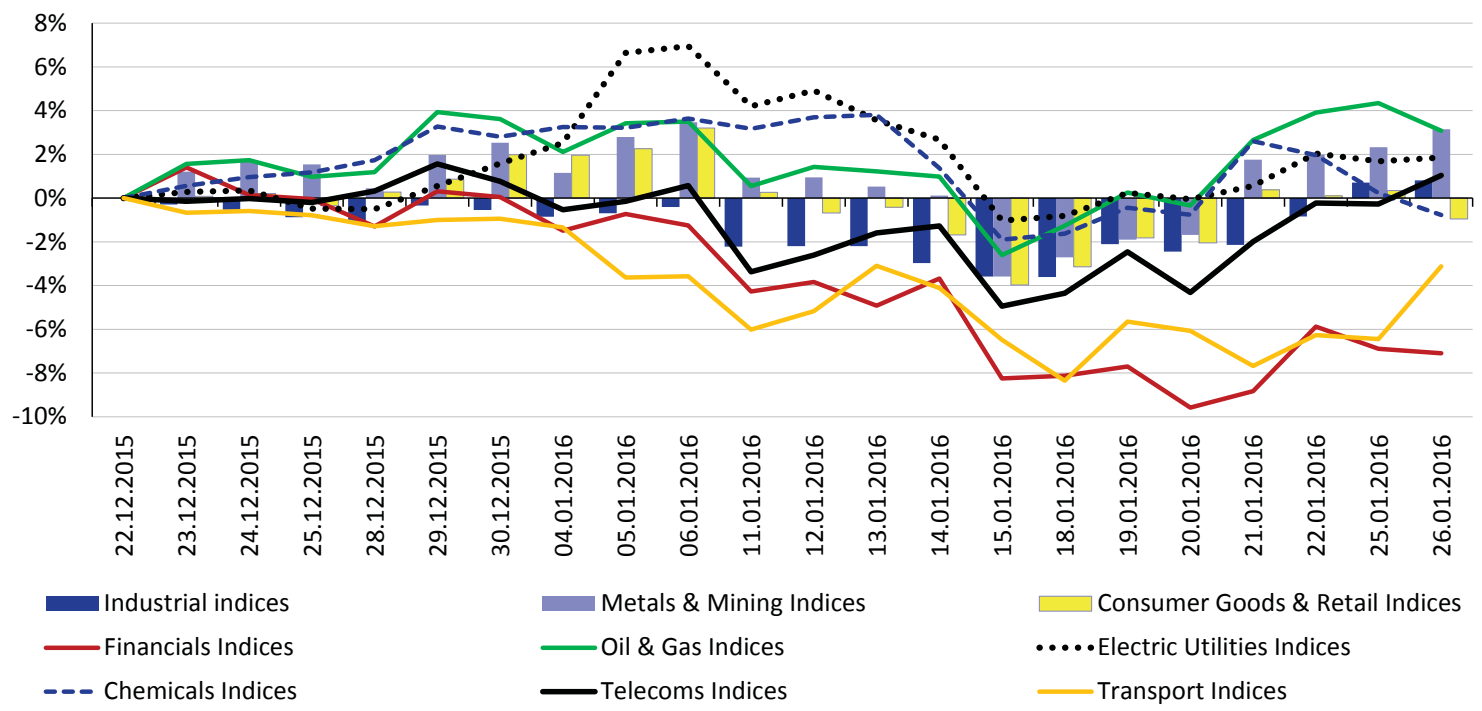

Sources: Quote RBC, the author's calculations.

Fig. 4. Growth rates in various MOEX sector indices in the period between 23 December 2015 and 26 January 2016

of the period under review, being equal to the average daily turnover of $\mathrm{Rb} 30.5 \mathrm{bn}$, at $9.1 \%$ below the value seen in the period under review and at $9.9 \%$ lower the last-year value, and $4.5 \%$ below the value seen in the same year-earlier period.

Sberbank accounted for $30.0 \%$ of MOEX total turnover in the period under review, its share shrank further by $2.2 \%$ from the previous period under review. Gazprom retained its share of MOEX total turnover at $13.0 \%$ (12.9\% a month earlier). LUKOIL and Norilsk Nickel were the third and the fourth largest companies of MOEX total turnover, $7.8 \%$ rounded to the tenths place). The yearly average turnover of Magnit, Surgutneftegaz, Rosneft and VTB was more than $\mathrm{Rb} 1 \mathrm{bn}$. The top- 3 companies accounted for $50.8 \%$ of MOEX turnover, and the rest five companies represented $26.8 \%$. The foregoing eight

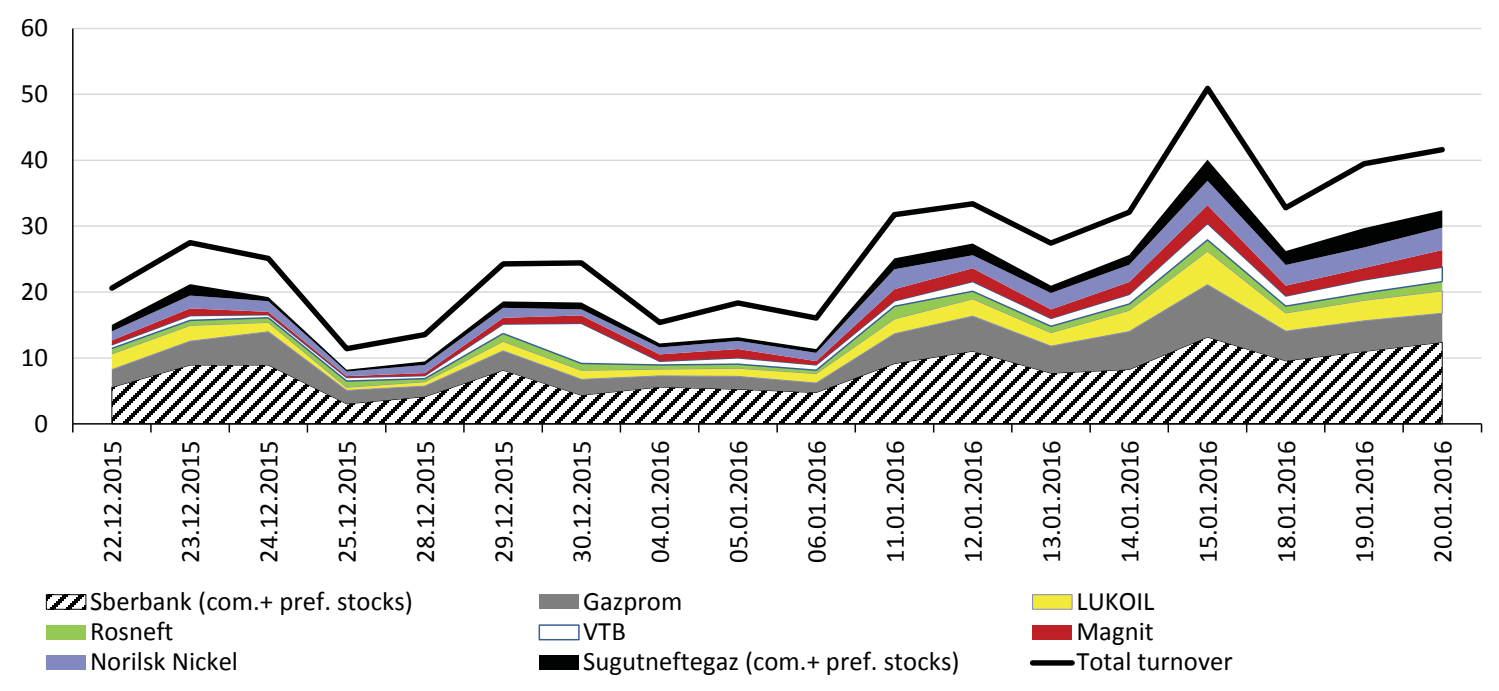

Sources: RBK Quote, author's calculations.

Fig. 5. The structure of MOEX turnover in the period between 23 December 2015 and 26 January 2016 
blue-chip stocks accounted for more than $3 / 4$ of all MOEX transactions $(77.6 \%)$, at merely $0.1 \%$ below the value seen a month earlier.

According to the data released by the Emerging Portfolio Fund Research (EPFR), Russia-focused mutual funds saw investments outflow further. Within two weeks - between 7 to 20 January 2016 - investors withdrew $\$ 161.8 \mathrm{~m}$ from such funds. At the same time, funds that invest only in Russian securities saw outflows worth $\$ 55.0 \mathrm{~m}$ during the same period.

MICEX capitalization as of 26 January 2016 remained unchanged compared with the previous period

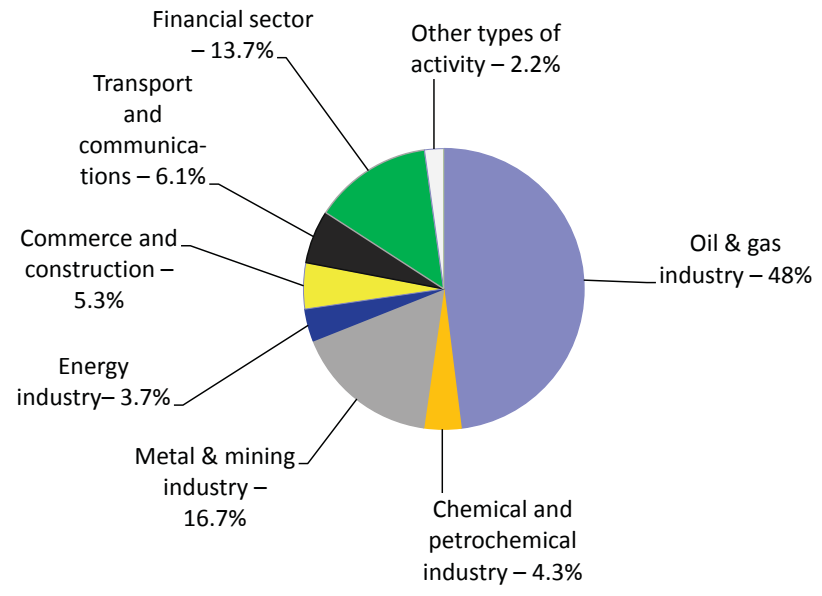

Sources: The Moscow Exchange official website, author's calculations.

Fig. 6. The stock market cap structure by type of economic activities as of 26 January 2016 under review, $\mathrm{Rb} 27.8$ trillion (compared with $\mathrm{Rb} 27.9$ trillion a month earlier). The marked fall of the stock of Sberbank and VTB was bound to reflect on changes to the stock market cap structure: Financials Indices shrank from $14.8 \%$ to $13.7 \%$. Metals \& Mining Indices increased $0.4 \%$ to $16.7 \%$ following three months of contraction. Oil \& Gas Indices were up $0.8 \%$. Other indices saw insignificant changes.

\section{Corporate bond market}

The volume of Russia's domestic corporate bond market (as measured by the par value of outstanding rouble-denominated securities including nonresidents' securities) earlier in 2016 continued to grow at minimum pace. Late in January, the volume reached an all-time high of $\mathrm{Rb} 7908.2 \mathrm{bn}$, up $0.9 \%$ from the value seen at 2014 year-end ${ }^{1}$. At the same time, At the same time, the elapsed period saw a small increase in both the number of outstanding bond issuances (1188 rouble-denominated corporate bond issuances were registered versus 1184 issuances at the end of December 2015) and the number of issuers in the debt segment ( 410 issuers versus 402 companies a month earlier. Nineteen Russian dollar-denominated bond issuances (worth a total of $\$ 6.5 \mathrm{bn}$ ) and a single JPY-denominated bond issuance (note that the issuer has entered into liquidation) remained outstanding in the market.

Investors' activity in the secondary corporate bond market dropped considerably. For instance, in the period between 22 December 2015 and 25 January 2016, the MOEX trading volume in rouble-denominated securities amounted to $\mathrm{Rb} 83.6 \mathrm{bn}$, reaching a local low in the recent 10 months (compared with the trading volume of $\mathrm{Rb} 132.4 \mathrm{bn}$ in the period between 24 November 2015 and 21 December 2015), whereas the number of transactions with securities during the same period reached its high of $34,100(28,100$ MOEX transactions were closed in the prior period) $)^{2}$. The mixed dynamics of the two indicators suggests that retail investors paid a relatively strong interest in securities.

The Russian Corporate Bond Market Index (IFX-Cbonds) continued to face a moderate uptrend. Late in January, the Index was up 4.4 index points (or

1 According to the data released by Rusbonds Information Agency.

2 According to the data released by Finam Investment Company. 
$1.0 \%)$ over the prior end-month value. The average weighted yield of corporate bonds followed facilitated the uptrend: it increased to $11.71 \%$ at end-January 2016 from $11.66 \%$ at end-December 2015 (Fig. 7) ${ }^{1}$. The corporate bond portfolio duration reversed after an unexpected growth late in 2015, reaching 320 days at end-January, making it 32 days shorter than the prior endmonth duration. Due to insignificant growth in the yield of bonds, these dynamics reflects a considerable increase in the average maturity of

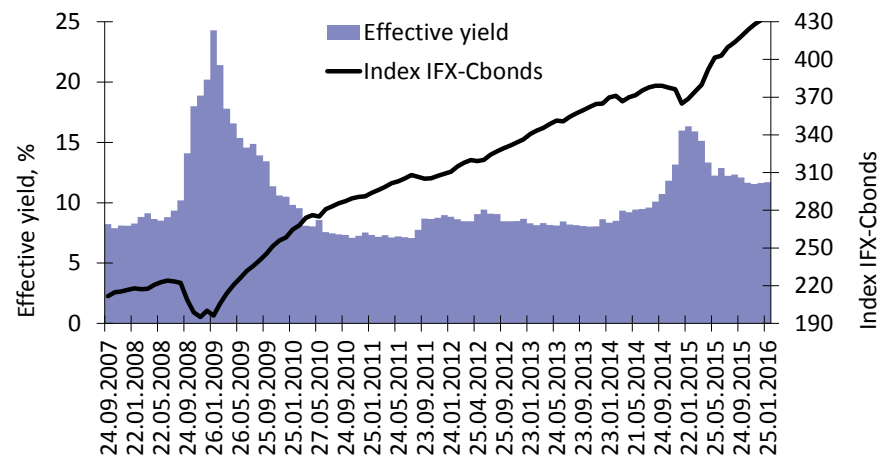

Source: According to the data released by Cbonds Information Agency.

Fig. 7. The dynamics of the Russian corporate bond market index and the average weighted yield securities in the market.

Late in December 2015 and January 2016, the Russian financial market was driven by heightened domestic economy risks, which in turn were caused largely by external factors. An extremely negative dynamics of crude oil prices were in the spotlight over the recent few weeks, which worsened the exchange rate of the Russian rouble and interest rates in the debt market. It is worth noting however that a correction took place by the end of January in the oil market and markets of other commodities ${ }^{2}$. Pessimistic sentiments in global financial markets were backed by the news of economic downside in some large countries (China, Japan, a few of the European states).

During the period under review, the most liquid segment of the domestic corporate bond market continued to face mixed dynamics of securities yield. The securities of financial companies were highly volatile. For instance, bond issuances of PAO AKBARS Bank, PAO Binbank, LLC Gazprom Capital and PAO Bashneft saw the deepest cuts in the interest rate (by two or more percentage points). At the same time, the securities of the State Corporation "Bank for Development and Foreign Economic Affairs (Vnesheconombank)" saw a similar growth in the yield ${ }^{3}$. Overall, the interest rate of highly liquid securities in the financial and industrial market segments faced considerable cuts (by an average of 0.4 percentage points), whereas telecom securities saw their yield grow. The securities of financial companies saw higher demand by investors during the period under review, whereas the energy segment was facing an extremely low trading volume, although as early as December 2015 the securities of major energy companies took the lead in terms of trading volume.

Issuers' activity in terms of seeking new fundraising during the period under review increased considerably despite a complex situation in the financial markets. For instance, 12 issuers registered 31 corporate bond issuances with an aggregate par value of $\mathrm{Rb} 229.8 \mathrm{bn}$ in the period between 22 December 2015 and 25 January 2016 (by comparison, 33 bond issuances worth $\mathrm{Rb} 203.0 \mathrm{bn}$ were registered in the period between 24 November 2015 and 21 December 2015. Prior to that period, the amount of monthly registered bond issuances ranged between $\mathrm{Rb} 50 \mathrm{bn}$ and $\mathrm{Rb} 80 \mathrm{bn})^{4}$. Additionally, a

1 According to the data released by Cbonds Information Agency.

2 According to the data released by Finam Investment Company.

3 According to the data released by Finam Investment Company.

4 According to the data released by Rusbonds Information Agency. 
single issuer registered a foreign-currency denominated bond issuance worth $\$ 60 \mathrm{~m}$. JSC SIBUR Holding, LLC Region-Invest, LLC Digital Invest and JSC United Engine Corporation issued the largest amount of registered bonds ${ }^{1}$. A few other bond programs are expected to register soon; in particular, Avangard Bank has approved an exchange-traded bond program worth a total of $\mathrm{Rb} 30 \mathrm{bn}$.

Investors' activity in the primary market dropped slightly below the yearly average level. For instance, 17 issuers placed 20 bond issuances worth a total of $\mathrm{Rb} 97.9 \mathrm{bn}$ in

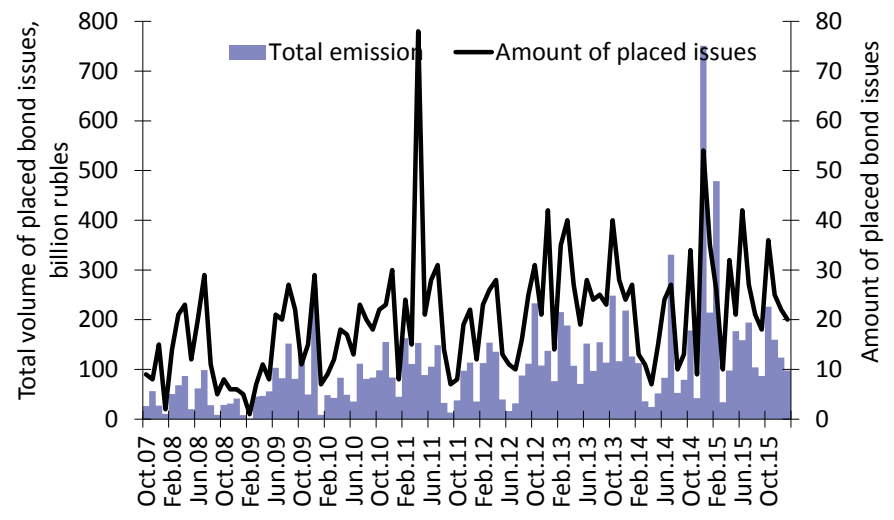

Source: According to the data released by Rusbonds information agency.

Fig. 8. The IPO dynamics of rouble-denominated corporate bonds the period between 22 December 2015 and 25 January 2016 (by comparison, 22 rouble-denominated bond issuances with an aggregate par value of $\mathrm{Rb} 123.5 \mathrm{bn}$ and a single foreign-currency denominated bond issuance worth $\$ 1.75 \mathrm{bn}$ were placed in the period between 24 November 2015 and 21 December 2015) (Fig. 8). Largest bond issuances were placed by JSC Atomenergoprom, LLC Akbars2 Mortgage Agent, JSC Russian Agricultural Bank and LLC Region-Invest ${ }^{2}$. Nearly half of the bond issuances placed during the period under review were exchange-traded bonds. A single mortgage agent managed to raise funds with a maturity of 32 years and four bond issuers raised funds with maturities of 10 to 15 years.

Late in December 2015 and January 2016 In December 2015, the Bank of Russia cancelled four corporate bond issuances of a single issuer Vozrozhdenie Bank - on the ground that not a single bond was issued (three corporate bond issuances were cancelled on the same grounds in the previous period under review) ${ }^{3}$, in which case the failure to issue bonds was caused by corporate events rather than troublesome market conditions.

In the period between 22 December 2015 and 25 January 2016, all the 10 issuers redeemed their 13 bond issuances with an aggregate par value of $\mathrm{Rb} 46.6 \mathrm{bn}$ (in the same prior period, all the issuers redeemed their bonds on the maturity date). Thirty three corporate bond issuances worth a total of $\mathrm{Rb} 190.7 \mathrm{bn}$ are due to mature in February $2016^{4}$.

However, the issue of companies defaulting on debt obligations due to their bond holders worsened considerably. Apart from a few technical defaults on meeting current debt obligations to bond holders and paying on the put date, seven issuers were declared in actual default ${ }^{5}$ on paying the coupon yield and on the put date (a few technical and actual defaults on various debt obligations were declared in the same prior period) ${ }^{6}$.

1 According to the data released by Rusbonds Information Agency.

2 According to the data released by Rusbonds Information Agency.

3 According to the data released by the Bank of Russia.

4 According to the data released by Rusbonds Information Agency.

5 That is, a bond issuer is unable to repay to bondholders even during the grace period.

6 According to the data released by Rusbonds Information Agency. 